\title{
Mangroves and Associated Flora of Vashista and Vainateyam Estuaries, A.P. India
}

\author{
Geddada Mohan NARASIMHA RAO, Pragada PRAYAGA MURTY
}

Andhra University, Department of Botany,Visakhapatnam, 530003, Andhra Pradesh, India; pragada007@gmail.com

\begin{abstract}
Mangroves are highly productive ecosystems occurs intertidal regions only. Mangroves and associated flora occurring in two major estuaries of Godavari river (India) were studied using transect with $4 \times 4 \mathrm{~m}^{2}$ quadrats and the quadrat samples were analyzed. Seasonal data were collected on environmental, hydrographical and chemical observations from three different stations of the two estuaries. Low values in Secchi depth, salinity and $\mathrm{pH}$ were reported during the monsoon season, while higher values were reported in pre-monsoon and post monsoon seasons. In the present study three mangrove species and nine associated species were reported. Transect studies in these two estuaries showed that mangrove and halophytes occurred up to 40 meters from water front region. In some places mangrove vegetation was in the form of long strips only. In Vainateyam estuary, the species with the highest density was Suaeda monoica whereas the species with lowest density was Avicennia officinalis. In Vashista estuary, maximum density was reported for Suaeda maritima and minimum density for Avicennia officinalis. The maximum height in these two stations varied from 5 to 8 meters only. Percentage frequencies of DBH (Density at Breast Height) classes were estimated. In the present study only two diameter classes were reported. This is indicative of the small and bushy mangrove vegetation in the region studied. Human interference, urban settlements and aqua industry play a critical impact on the survival of these tropical ecosystems. If management and conservation programmes are not undertaken, these ecosystems may be depleted.
\end{abstract}

Keywords: mangrove, associated flora, Vashista, Vainateyam estuaries, Andhra Pradesh, India

\section{Introduction}

Mangrove ecosystems of Gautami Godavari estuary (India) received much attention on mangrove flora and estuarine algae (Rao, 1959; Sidhu, 1963; Raju, 1968; Blasco, 1988; Narasimha Rao, 1989, 1995; Krishna Rao and Narasimha Rao, 1994; Narasimha Rao and Umamaheswara Rao, 1991; Bhaskara Rao, 1992; Narasimha Rao et al., 2000; Venkaiah and Prayaga Murty, 2007; Narasimha Rao and Dora, 2009). Godavari delta spreads from Chollangi near Kakinada to Anthervadi near Narsapuram. Lot of work has been done in the mangroves of Gautami major and minor estuaries of River Godavari. No report was available in literature regarding the presence of mangroves in Vashista and Vainateyam estuaries of Godavari River. In the present study quantitative information was collected on the mangrove populations of Vashista Godavari and Vainateyam Godavari estuaries of Andhra Pradesh.

\section{Materials and methods}

The river, Godavari is the largest among the rivers of South India and is held in references as Dakshina Ganga. At the head of its delta, the river branches into Gautami and Vashista. The Gautami branch of Godavari is a typical positive estuary and is in tidal communication with the open sea up to a point near Kapileswarapuram. This branch flows south west and opens into Bay of Bengal at two places namely Bhiravapalem and Kothapalem. Vashis- ta branch of Godavari flows south east and divided into two branches namely Vashista and Vainateyam and opens into Bay of Bengal at two places namely Anthervadi and Karawaka near Gogannamatam respectively. Near the confluence (Karawaka) muddy and swampy regions exists, harbouring the mangrove and halophytic vegetation from Karawaka to Gogannamatam. In Gogannamatam on either side of the river some muddy platform occur, which harbors both mangrove and halophytic vegetation. Height and growth of the mangroves reduced towards the Gogannamatam. Vashista branch of Godavari merges into Bay of Bengal near Anthervadi. In this estuarine region mangrove vegetation spreads up to $8 \mathrm{~km}$ only. Two stations were selected in Vainateyam estuary and one station at Vashista estuary, Environmental; hydrographical and chemical features such as air, water temperatures, salinity, and $\mathrm{pH}$, D.O and water transparency were collected at three study sites from February 2009 to January 2010. Surface water samples were taken near the study sites for collection of data. Temperature, $\mathrm{pH}$ and salinity were measured with a thermometer, portable $\mathrm{pH}$ meter and salinometers respectively; transparency of water was estimated by Secchi disc. Dissolved oxygen was estimated by the method followed by Strickland and Parsons (1972). Sediment analysis of the soil samples in mangrove region was carried out by using the pipette method (Carver, 1971). Quantitative data were collected by placing transect from shore to interior of the forest and extending transect up to the barren zone to obtain the real status of the forest cover; quadrat of $(4 \times 4$ 


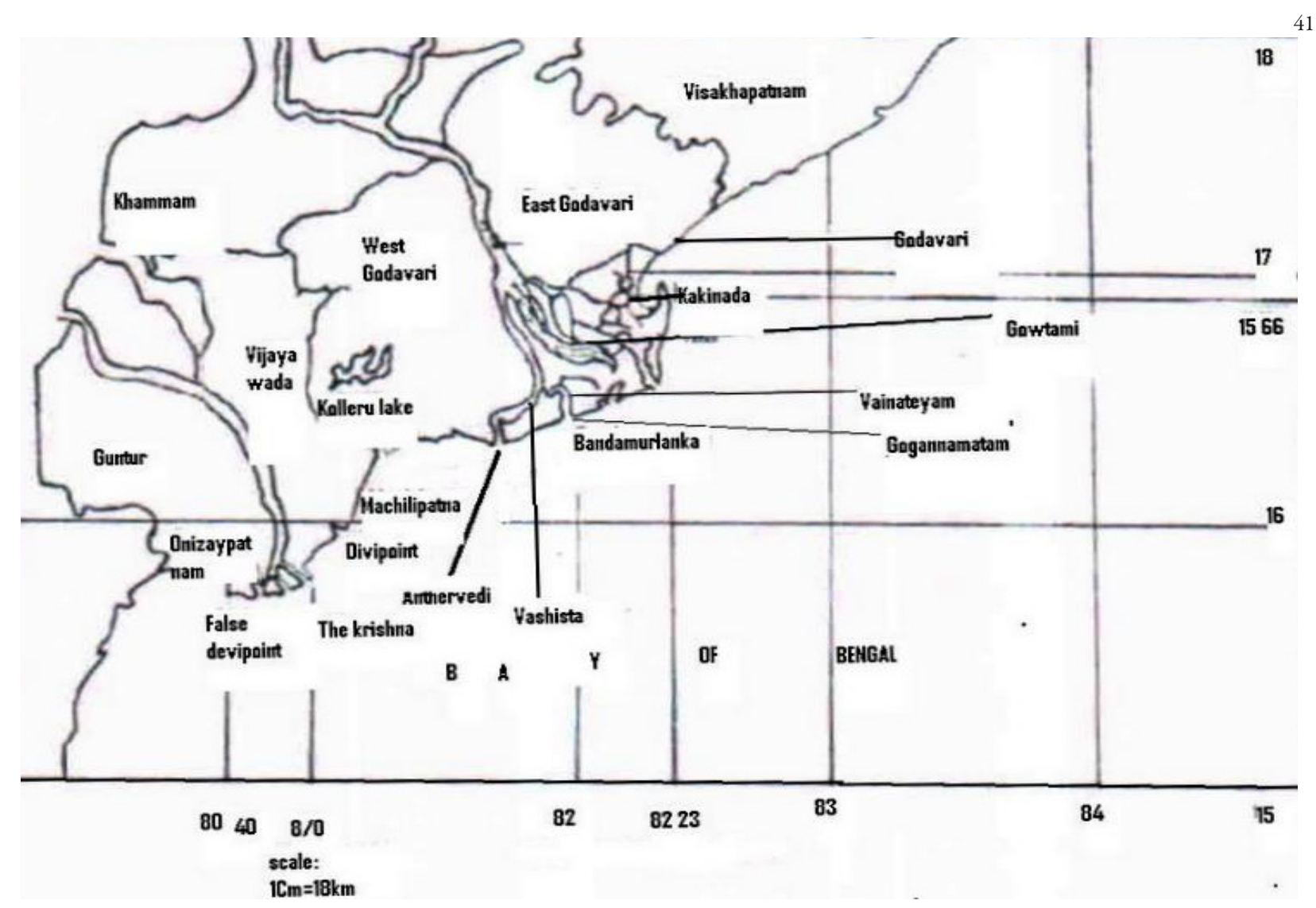

41

Fig. 1. Vashista and Vainateyam estuaries

$\mathrm{m}^{2}$ ) was marked along the transect line at $5 \mathrm{~m}$ interval from water front to end of the forest. A total of 15 transects (5 in each station) were collected for tabulation of data and plants present in each quadrat $\left(4 \times 4 \mathrm{~m}^{2}\right)$ were counted. Quadrat samples collected from the different stations were analyzed and densities of different species were estimated. DBH of all plants present in all quadrats were measured to estimate relative abundance of different diameter classes of mangroves in all stations (Fig. 1).

\section{Results}

\section{Hydrographical observations}

The Godavari empties about 240x10 cubic feet per second of water each year into the Bay of Bengal. This large volume of fresh water, loaded with sediments, flows through a number of distributaries into the Godavari delta covering an area of $6500 \mathrm{~km}$. Mangroves penetrate only a short way upstream in the estuaries of Vainateyam and Vashista rivers and in some drainage channels. Mangroves penetrate only some 8 to $10 \mathrm{~km}$ from the mouth. The estuarine and adjacent coastal waters are enriched by the discharge of nutrient rich waters from the rivers and by detritus derived from the primary production of the mangrove forests, which are part of the estuarine ecosystem since they grow intertidal. In the Vainateyam River, mangroves forest extends up to Adurru, $10 \mathrm{~km}$ inland. Plants such as Avicennia, Acanthus and Suaeda are predominant forms in this estuary. In Vashista estuary, mangrove forest along the banks of the estuary only. Halophytes are most dominant forms in this estuary.

Seasonal data collected on environmental, hydrographical and chemical studies of different stations of Vashista and Vainateyam estuaries was presented in (Tab. 1.) Dur-

Tab. 1. Seasonal changes in the hydrographical features of different stations of Vashista and Vainateyam Godavari estuaries

\begin{tabular}{|c|c|c|c|c|c|c|c|c|c|c|}
\hline \multirow{2}{*}{ No } & & \multicolumn{3}{|c|}{ Pre monsoon } & \multicolumn{3}{|c|}{ Monsoon } & \multicolumn{3}{|c|}{ Post monsoon } \\
\hline & & $\mathrm{St}_{1}$ & $\mathrm{St}_{2}$ & $\mathrm{St}_{3}$ & $\mathrm{St}_{1}$ & $\mathrm{St}_{2}$ & $\mathrm{St}_{3}$ & $\mathrm{St}_{1}$ & $\mathrm{St}_{2}$ & $\mathrm{St}_{3}$ \\
\hline 1 & Air temperature & 29.0 & 29.5 & 29.0 & 26.5 & 27.0 & 27.0 & 24.5 & 24.0 & 24.5 \\
\hline 2 & Water temperature & 24.0 & 24.5 & 24.0 & 22.5 & 23.0 & 22.0 & 21 & 21.5 & 21.5 \\
\hline 3 & Secchi $\operatorname{disc}(\mathrm{cm})$ & 25 & 23 & 25 & 14 & 15 & 14 & 18 & 20 & 20 \\
\hline 4 & Salinity(\%o) & 30 & 31 & 31 & 23.0 & 24.5 & 24.0 & 27 & 27.5 & 27.0 \\
\hline 5 & $\mathrm{pH}$ & 7.1 & 7.0 & 7.1 & 7.2 & 7.1 & 7.2 & 7.2 & 7.2 & 7.1 \\
\hline 6 & D.O $(\mathrm{ml} / \mathrm{L})$ & 7.2 & 7.4 & 7.3 & 7.3 & 7.2 & 7.3 & 7.4 & 7.3 & 7.3 \\
\hline
\end{tabular}


42

Tab. 2. Density of various plant populations estimated at various stations of Vainateyam and Vashista estuaries

\begin{tabular}{|c|c|c|c|c|c|}
\hline \multirow[t]{2}{*}{ No. } & \multirow{2}{*}{$\begin{array}{l}\text { Name of } \\
\text { the species }\end{array}$} & \multirow[t]{2}{*}{ Family } & \multicolumn{3}{|c|}{$\begin{array}{c}\text { Density } \\
\text { individual /hectare }\end{array}$} \\
\hline & & & $\mathrm{St}_{1}$ & $\mathrm{St}_{2}$ & $\mathrm{St}_{3}$ \\
\hline 1 & $\begin{array}{l}\text { Acanthus } \\
\text { ilicifolius }\end{array}$ & Acanthaceae & 925 & 864 & 586 \\
\hline 2 & $\begin{array}{c}\text { Arthrocnemum } \\
\text { indicum }\end{array}$ & Chenopodiaceae & 974 & 486 & 674 \\
\hline 3 & $\begin{array}{l}\text { Avicennia } \\
\text { marina }\end{array}$ & Verbenaceae & 124 & 75 & 98 \\
\hline 4 & $\begin{array}{l}\text { Avicennia } \\
\text { officinalis }\end{array}$ & Verbenaceae & 88 & 34 & 67 \\
\hline 5 & $\begin{array}{l}\text { Clerodendrum } \\
\text { inerme }\end{array}$ & Verbenaceae & 116 & 86 & 88 \\
\hline 6 & Cressa cretica & Convolvulaceae & 81 & 76 & 69 \\
\hline 7 & $\begin{array}{c}\text { Sesuvium } \\
\text { portulacastrum }\end{array}$ & Aizoaceae & 962 & 861 & 1021 \\
\hline 8 & $\begin{array}{l}\text { Excoecaria } \\
\text { agallocha }\end{array}$ & Euphorbiaceae & 152 & 98 & 124 \\
\hline 9 & $\begin{array}{l}\text { Suaeda } \\
\text { maritima }\end{array}$ & Chenopodiaceae & 1260 & 1170 & 1456 \\
\hline 10 & Suaeda monoica & Chenopodiaceae & 1520 & 1220 & 1368 \\
\hline 11 & Derris horrida & Fabaceae & 64 & 57 & 74 \\
\hline 12 & $\begin{array}{l}\text { Prosophis } \\
\text { chinensis }\end{array}$ & Fabaceae & 840 & 672 & 796 \\
\hline
\end{tabular}

ing the period of study air temperature ranges from 24.0 to $29.5^{\circ} \mathrm{C}$ lower air and water temperature were observed during winter season and higher values were reported in pre monsoon/ summer months transparency of the surface waters varies from 14 to $25 \mathrm{~cm}$, minimum in rainy season and maximum in pre monsoon season, salinity and $\mathrm{pH}$ of the surface water shows same trend like Secchi disc or water transparency values and dissolved oxygen of the surface water ranges from 7.2 to $7.4 \mathrm{ml}$.

\section{Composition and density of mangrove species}

Data collected on distribution and density of mangrove populations in Vainateyam and Vashista estuaries of Godavari River was presented in (Tab. 2.) Densities of the individual plant species was estimated based on collected quadrat samples in all transect were pooled and calculated the number of plant species per hectare. In Vainateyam estuary $\left(\mathrm{St}_{1}\right.$ and $\left.\mathrm{St}_{2}\right) 12$ mangrove and associated species were reported with a high density for the species for Suaeda monoica, 1520 plants/ hectare in $\mathrm{St}_{1}$, followed by Suaeda maritima, 1260 plants/ hectare in St. Minimum density of the plant species was reported for the species Avicennia officinalis (34 plants/hectare) in $\mathrm{St}_{2}$ and 64 plants/hectare for the species Derris horrida. Height of the mangrove plants varies from 5-8 $\mathrm{m}$ in two stations of the Vainateyam estuary. In this study three true mangrove species and nine associated flora and halophytes were reported. In station 1 density, abundance and height of the mangroves were more than the station 2 of the Vainateyam estuary.
Tab. 3. Percentage frequency of DBH classes for mangroves in the three stations

\begin{tabular}{|c|c|c|c|c|c|c|c|}
\hline \multirow{3}{*}{ No. } & \multirow{3}{*}{$\begin{array}{l}\text { Name of } \\
\text { the species }\end{array}$} & \multicolumn{6}{|c|}{ Plant diameters $(\mathrm{cm})$} \\
\hline & & \multicolumn{2}{|c|}{$\mathrm{St}_{1}$} & \multicolumn{2}{|c|}{$\mathrm{St}_{2}$} & \multicolumn{2}{|c|}{$\mathrm{St}_{3}$} \\
\hline & & $0-10$ & $10-20$ & $0-10$ & $10-20$ & $0-10$ & $10-20$ \\
\hline 1 & $\begin{array}{l}\text { Acanthus } \\
\text { ilicifolius }\end{array}$ & 100 & -- & 100 & -- & 100 & -- \\
\hline 2 & $\begin{array}{l}\text { Arthrocnemum } \\
\text { indicum }\end{array}$ & 100 & -- & 100 & -- & 100 & -- \\
\hline 3 & $\begin{array}{l}\text { Avicennia } \\
\text { marina }\end{array}$ & 61 & 39 & 58 & 42 & 65 & 35 \\
\hline 4 & $\begin{array}{l}\text { Avicennia } \\
\text { officinalis }\end{array}$ & 78 & 22 & 85 & 15 & 80 & 20 \\
\hline 5 & $\begin{array}{c}\text { Clerodendrum } \\
\text { inerme }\end{array}$ & 65 & 35 & 71 & 39 & 68 & 32 \\
\hline 6 & Cressa cretica & 100 & -- & 100 & -- & 100 & -- \\
\hline 7 & $\begin{array}{c}\text { Sesuvium } \\
\text { portulacastrum }\end{array}$ & 100 & -- & 100 & -- & 100 & -- \\
\hline 8 & $\begin{array}{l}\text { Excoecaria } \\
\text { agallocha }\end{array}$ & 42 & 58 & 55 & 45 & 49 & 51 \\
\hline 9 & $\begin{array}{l}\text { Suaeda } \\
\text { maritima }\end{array}$ & 100 & -- & 100 & -- & 100 & -- \\
\hline 10 & Suaeda monoica & 100 & -- & 100 & -- & 100 & -- \\
\hline 11 & Derris horrida & 100 & -- & 100 & -- & 100 & -- \\
\hline 12 & $\begin{array}{l}\text { Prosophis } \\
\text { chinensis }\end{array}$ & 100 & -- & 100 & -- & 100 & -- \\
\hline
\end{tabular}

In Vashista estuary $\left(\mathrm{St}_{3}\right)$ mangrove vegetation is scanty when comparing with Vainateyam estuary. Most of the vegetation is bushy type with few trees of Avicennia and Excoecaria species. Density of the plant population is relatively low than Vainateyam estuary. In this station also a total of 12 species were reported (Tab. 2). Data collected on density of plants/hectare reveals that same trend also observed like Vainateyam estuary. Maximum density of the plant species was reported for Suaeda maritima (1456 plants/hectare) and Suaeda monoica (1368 plants/ hectare) and minimum density for Avicennia officinalis (67 plants/hectare).

\section{DBH classes of the mangrove species in different study} stations of the two estuaries

The relative abundance of different diameter classes of mangroves, associated flora and halophytes of the two estuaries reflects that more $75 \%$ of plants growing in two estuaries are under $0-10 \mathrm{~cm}$ diameter class. Only four species of Avicennia marina, Avicennia officinalis, Clerodendrum inerme and Excoecaria agallocha are larger species and their average diameter was between 10 and $20 \mathrm{~cm}$ diameter class. These findings on the mangrove vegetation of Vashista and Vainateyam estuaries indicate that forest is scanty and bushy type (Tab. 3).

\section{Mangrove sediments}

Data on sediment analysis of soil sample in the three stations of Vainateyam and Vashista estuaries of Godavari 
river shows that the high percentage of sand $32 \%$ to $41 \%$, low percentage of silt $12 \%$ to $24 \%$ and clay $21 \%$ to $30 \%$. In general mangroves are observed where silt content is more than $50 \%$.

\section{Discussion}

Hydrographical conditions of the Gautami branch of the Godavari estuary have not studied in detail. Narasimha Rao (1989) has collected the information on hydrography and physico-chemical conditions of Godavari estuary, and reported that air and water temperatures, salinity and $\mathrm{pH}$ were high during summer and early monsoon months from March to June. Secchi disc or water transparency was more in summer months. This is due to more rainfall and more water discharge during rainy season. In the present study air, water temperature, salinity, $\mathrm{pH}$, water transparency were more during pre monsoon season and low in monsoon and post monsoon seasons as reported by (Narasimha Rao, 1989).

Mangroves are typical ecosystems regularly influenced by high tide and low tides of the sea. In both of Vainateyam and Vashista estuaries width of the mangrove cover is very narrow at many places due to lack of sufficient inundation. Mangrove forest extends up to 40 meters from the water front zone. Transect studies reveals that halophytes are present very near to barren zone. Formations of these halophytic plants are purely due to lack of sufficient inundation up to this part of the forest. Water reaches up to this region only in high tide periods. In the Godavari estuary, Rao and Rao (1988) reported that nearly 40\% of the total individuals belonging to species like Suaeda maritima and Suaeda monoica. Excoecaria agallocha were found to be the dominant species in the Godavari estuary and its density was nearly $22 \%$ of the total density. The other mangrove accounted for $38 \%$ of the total density. In the Krishna estuary (Venkanna and Narasimha Rao, 1993), plants like Suaeda maritima, Suaeda monoica and Excoecaria agallocha were found to be dominant species and density of plant species are less in Krishna estuary but number of plant species was more than the Godavari estuary. In the present study on mangroves of Vainateyam and Vashista estuaries of Godavari river also reveals that mangrove vegetation of these two estuaries comprises with the populations of Suaeda maritima, Suaeda monoica and Excoecaria agallocha. More than $75 \%$ of the forest composed with halophytic flora only.

Sediment analysis of soil sample in the three stations of Vainateyam and Vashista estuaries of Godavari river shows that the high percentage of sand $32 \%$ to $41 \%$, low percentage of silt $12 \%$ to $24 \%$ and clay $21 \%$ to $30 \%$. In general mangroves are observed where silt content is more than $50 \%$. Result of the present study agrees with the earlier studies of (Bhaskara Rao et al., 1992) and (Narasimha Rao and Dora, 2008) on mangrove sediments of Godavari estuary. Indiscriminate cuttings of the mangroves for wood, firewood and other purposes are increasing in these regions. Besides application of fertilizers and pesticides in the paddy fields may be one of the important factors for increasing the pollution in the estuarine habitats. Further, spreading the aqua industry for culture of fish and shrimp may be responsible for depleting the beautiful tropical intertidal ecosystems.

\section{Acknowledgements}

One of the Authors (GMNR) is thankful to the UGC, SAP for providing funds for field study and Head, Department of Botany, Andhra University, Visakhapatnam for facilities.

\section{References}

Blasco, F. (1975). The Mangroves of India, Pondicherry, French Sectariat Science and Technology 14:1-175.

Bhaskara Rao, V., G. M. Narasimha Nao, G. V. S. Sarma and B. Krishna Rao (1992). Mangrove and its sediment characters in Godavari estuary, east Coast of India. Indian Journal Marine Science 21:64-66.

Carver, R. E. (1971). Sedimentary petrology. John Wiley and Sons Inc, Ed. London.

Krishna Rao, B. and G. M. Narasimha Rao (1992). Mangrove Resources in Godavari and Krishna estuaries: Management and perspectives. Indian J. of Landscape Systems 15:96-99.

Narasimha Rao, G. M. (1989). Ecological studies on some estuarine and marine algae, Ph.D. Thesis, Andhra University. Andhra Pradesh.

Narasimha Rao, G. M. (1995). Seasonal Growth, Biomass, And Reproductive behavior three species of Red algae in Godavari estuary. India Journal Phycology 31(2):209-214.

Narasimha Rao, G. M. (2008). Mangrove populations of Visakhapatnam and Sarada and Varaha estuarine complex, India. International Journal of Plant Sciences 3(2):686-687.

Narasimha Rao, G. M. and S. V. V. S. N. Dora (2009). An experimental approach to Mangroves of Godavari estuary. Indian Journal of Forestry 32(3):263-265.

Narasimha Rao, G. M., B. N.,Rao, K. S. N. Reddy and D. Varma (2000). Ecology and physiology of Halophila ovalis (R. Br.) Hk. F. at Pandi back waters, Andhra Pradesh. Ecology Environment and Conservation 6(3):297-300.

Raju, D.C.S. (1968). The vegetation on West Godavari. Proceedings National Symposium on Recent Advances in Tropical Ecology, Banaras Hindu University, Varanasi.

Rao, R. S. (1959) Observations on the mangrove vegetation of the Godavari estuary. In: Proceedings of the mangrove symposium, Calcutta.

Sidhu, S. A. (1963). Studies on the mangroves of India 1. East Godavari region. Indian Forester 86:337-351.

Venkaiah, M. and P. Prayaga Murty, (2007). A Rare Mangrove "Sonneratia caseolaris" in Coringa Mangrove Forest Area, East Godavari, Andhra Pradesh. Proc. A.P. Academi of Sciences, Hyderabad 11(3)2007:188-190.

Venkanna, P. and G. M. Narasimha Rao (1993) Distribution pattern of the mangroves in the Krishna estuary. Indian Journal of Foresty 16:48-53. 